\author{
Rafis Abazov \\ Earth Institute at Columbia University, New York, USA \\ Honorary Director MDP Global Classroom Program \\ Joint Program between Al Farabi KazNU and MDP Program at Earth Institute at Columbia University \\ e-mail: r.abazov@yahoo.com
}

\title{
EDUCATION FOR SUSTAINABLE DEVELOPMENT AND ICT: THE CASE OF MDP PROGRAM AT AL-FARABI KAZNU
}

Many universities from around the world - including in Kazakhstan - work on incorporating the Sustainable Development Goals (SDGs) into educational programs and the educational process as part of developing a new approach in adapting curricular and entire educational modules to realities of the modern economy, green development and global cooperation on Agenda 2030. The SDGs provide a new framework for organizing the learning process in higher education and moving it closer to both labour market needs and green economy demands. There are different views and approaches in dealing with new SDG-related educational agendas.

The purpose of this article is to analyses the changing approaches to organizing the educational process and incorporating the SDG agenda into curricula, using the example of Kazakhstan. First, it assesses the theoretical aspects of incorporating an SDG agenda into the educational process by looking at how the Theory of Change has affected the formulation of the concept of education for sustainable development. Second, it analyses the international experience in developing programs on education for sustainable development by looking at the MDP program, a pioneering program developed by Columbia University in collaboration with the MDP global network. Third, it presents as a case study the introduction of the MDP Global Classroom Program at Kazakh National University, Almaty, Kazakhstan, and discusses a decade of the program's functioning in Kazakhstan (2011-20). The conclusion summarizes the findings of this article and discusses some implications for education policies and practices.

Key words: Education for sustainable development, Information and Communication Technologies (ICT), Sustainable Development Goals (SDGs), Theory of Change, Kazakhstan, Central Asia.

\section{Рафис Абазов}

Колумбия университетіндегі Жер институты, АҚШ, Нью-Йорк қ., Әл-Фараби атындағы ҚазҰУ және Колумбия университетінің Жер институты MDP Global Classroom бірлескен бағдарламасының құрметті директоры e-mail: r.abazov@yahoo.com

\section{Тұрақты даму және акт үшін бікім: әл-Фараби атындағы ҚазҰУ-дағы тұрақтылық бойынша MDP бағдарламасының жағдайы}

\footnotetext{
Ә^емдегі көптеген университеттер, соның ішінде Қазақстан, 2030 жылға дейін Тұрақты Ааму Мақсаттарын (ТАM) оқу жоспарлары мен бүкіл оқу модульдерін қазіргі заманғы экономика, жасы^ даму және жаһандық ынтымақтастықтың нақты күн тәртібіне сәйкестендірудің жаңа әдісін әзірлеу шеңберінде білім беру бағларламалары мен білім беру үлерісіне интеграциялау бойынша жұмыс істейлі. ТАМ жоғары білім беруді ұйымдастырудың және оны еңбек нарығының қажеттіліктеріне және жасыл экономика талаптарына жақындатудың жаңа негіздерін ұсынады. ТАМ-ге қатысты жаңа білім берудің күн тәртібіне қатысты әртүрлі көзқарастар мен тәсілдер бар. Мақалада білім беру үлерісін ұйымдастырудағы өзгеретін тәсілдер мен ТАМ күн тәртібін оқу жоспарларына Қазақстан мысалының көмегімен енгізу та^данады. Біріншіден, «Өзгерістер теориясының» тұрақты дамуға білім беру тұжырымдамасын құруға қалай әсер еткендігін ескере отырып, ТАМ күн тәртібін білім беру үАерісіне интеграциялаудың теориялық, аспектілері бағаланады. Екіншіден, Колумбия университетінің жаһандық MDP желісімен бірлесіп жасаған инновациялық бағдарламасын - MDP бағдарламасын ескере отырып, тұрақты даму үшін білім беру бағдарламаларын жасаудың халықаралық тәжірибесін талдайды. Үшіншіден, мақалада Қазақ ұлттық университетінде (әл-Фараби атындағы ҚазҰУ), Алматы қ., Қазақстан, MDP ғаламдық оқу жоспарын іске асырудың жағдайлық зерттеуі келтірілген, оның ішінде Қазақстандағы MDP бағдарламасының он жылдық тәжірибесін талдау (2011-2020 жж.). Қорытынды бөлімде осы
} 
мақаланың шешуші фактілері келтіріліп, білім беру саясаты мен тәжірибесінің кейбір са^дары талқыланады.

Түйін сөздер: Тұрақты дамуға білім беру, Ақпараттық-коммуникациялық технологиялар (AKT), Тұрақты даму мақсаттары (ТАМ), өзгеріс теориясы, Қазақстан, Орталық Азия.

\author{
Рафис Абазов \\ Институт Земли при Колумбийском университете, США, г. Нью-Йорк \\ Почетный Аиректор совместной программы КазНУ им. аль-Фараби \\ и Института Земли Колумбийского университета MDP Global Classroom \\ e-mail: r.abazov@yahoo.com \\ Образование в интересах устойчивого развития и ИКТ: \\ кейс-программы MDP по устойчивому развитию в КазНУ им. аль-Фараби
}

\begin{abstract}
Многие университеты мира, в том числе и казахстанские, работают наА включением Целей устойчивого развития (ЦУР) в образовательные программы и образовательный процесс. Происходит это в рамках разработки нового подхода к аАаптации учебных программ и целых учебных модулей к реалиям современной экономики, зеленого развития и глобального сотрудничества по Повестке Аня на период до 2030 года. ЦУР обеспечивают новую основу Аля организации высшего образования и приближения его к потребностям рынка труда и требованиям зеленой экономики. Существуют разные взгляды и подходы к работе с новой повесткой дня в области образования, связанной с ЦУР.

Цель данной статьи - проанализировать меняющиеся подходы к организации образовательного процесса и вк^ючению повестки ЦУР в учебные планы на примере Казахстана. Вопервых, оцениваются теоретические аспекты включения повестки дня ЦУР в образовательный процесс с учетом того, и каким образом «Теория изменений» повлияла на формулировку концепции образования Аля устойчивого развития. Во-вторых, анализируется международный опыт разработки программ по образованию Аля устойчивого развития с учетом программы MDP, новаторской программы, разработанной Колумбийским университетом в сотрудничестве с глобальной сетью MDP. В-третьих, статья преАставляет кейсовое исследование (casestudy), внедренное Глобальной учебной программой MDP в Казахском национальном университете (КазНУ им. аль-Фараби) (А^маты, Казахстан), вк^ючая анализ десятилетнего опыта работы программы MDP в Казахстане (2011-2020 годы). В заключении суммируются выводы, слеланные в этой статье, обсуждаются некоторые послеАствия Аля политики и практики в области образования.
\end{abstract}

Ключевые слова: образование Аля устойчивого развития, Информационные и коммуникационные технологии (ИКТ), Цели устойчивого развития (ЦУР), Теория изменений, Казахстан, Центральная Азия.

\section{Introduction}

Since the 1980s-1990s, universities from around the world have been working on introduction of education for sustainable development into the Higher Education Institutions (HEI) dealing with the internationalization of education in general and working on creating local content within the HEI in particular. Managers, higher education strategic planners and public policy practitioners have been working on responses to these challenges of introduction of education for sustainable development into curricular. Among other things, they have been conceptualizing multidisciplinary approaches and debating the current and future development of the education for sustainable development at the national and international levels. The education for sustainable development has emerged as one of the influential concepts, which have helped to align major stakeholders in promoting sustainable development not only in the HEI but also in the global society as well. It also emerged as an important part of the concept of the Sustainable Development Goals introduced by the UN.

The discourses around the introduction of education for sustainable development at the international and regional levels have had a significant impact on discourses at the national level. For example, in the case of Kazakhstan, HEI's managers and strategic planners focused on the internationalization of the education system and on the technological changes considering that, the integration of the conceptual framework of education for sustainable development into the curricular would improve international competitiveness of Kazakhstan's universities.

Several international studies completed by the international organizations and various international 
experts (UNESCO, 2014) suggest that there is a growing impact of the universities on the "green" thinking and "green" policy planning.

The study of integration of education for sustainable development at the national level in the context of Kazakhstan raises several questions. The goal of this paper to address the research questions as follows: How can we conceptualize introduction of education for sustainable development utilizing the Theory of Change (ToCh)? How did the concept of education for sustainable development evolve over the time and how it influenced the thinking about modern educational process? How was education for sustainable development being introduced at the national level in Kazakhstan?

This paper attempts to answer these and other questions using an example of Kazakhstan. In order to address the research questions this paper is organized as follows: First section overviews the theoretical background discussing the ToCh and its impact on conceptualizing education for sustainable development. Second section analyses the evolution of education for sustainable development and its impact in popularizing sustainable development. Third section evaluates the major steps in framing, conceptualizing and introducing education for sustainable development at Al Farabi KazNU. The conclusion summarizes the main findings of the article.

\section{Theoretical aspects, the SDG agenda and the educational process}

This chapter discusses Theory of Change (ToCh) in the context of the evaluation of social and economic development, and its impact on the formulation of major principles of education for sustainable development.

ToChrepresents an important approach in dealing with some of today's major challenges as it emerged also in a time of changes and challenges. ToCh traces its roots to the academic debates of the 1950s and -1960 s - the "era of decolonization" - when a significant number of scholars were attempting to explain causal relationships between social and economic changes and programs of development (Janos, Andrew C., 1986). The experience of international organizations in developing countries during that era illustrated that social and economic development is not always linear. There are many factors that affect attempts to introduce changes and development. As scholars and policy practitioners continued working on plausible explanations underlying the issues of effective development and actual (real) changes from both theoretical and practical points of view, ToCh has become an influential concept employed by development scholars and practitioners (Kubisch, A., 1997).

ToCh not only offers a plausible theoretical framework to explain change, it also offers a feasible practical framework for working on change. ToCh explains change as the development of a causal chain in major development initiatives. Adherents of the theory have suggested dividing change into interconnected chains of short-term, mid-term and long-term activities. The result achieved in each step has an impact on the next result in the logical chain of activities. Thus, ToCh has very practical implications as it makes it possible to more effectively line up (modulate) expected results in the process of formulation and implementation of development programs.

ToCh can be used to formulate the line of expected changes even in an intertwined and complex program of development as it helps to modulate expected results at different levels, and to correlate those results with the realities of various developmental situations and in different environments (Kubisch, A., 1997).

In the context of introduction of educational programs for sustainable development, ToCh helps not only to explain the impacts of education for sustainable development and to formulate the program of development and change, but also to forecast possible results in the multidimensional environment of the education process (see discussion: Jahdhami, Adnan Al, 2019).

Indeed, the integration of programs or modules on education for sustainable development into the existing traditional mechanisms of the educational process poses a great challenge. This integration requires the correct evaluation of a causal chain of relationships, impacts and activities of new educational programs, and the evaluation of feedbacks from the existing system of education which relies on established traditions and programs.

Education for sustainable development requires the integration of a complex multidisciplinary approach to developing knowledge and practical skills among students, educators and researchers (more detailed discussion is presented in the next chapter). Education for sustainable development combines elements of both traditional and novel educational programs as well as teaching/training approaches and methodologies. In addition, the introduction of education for sustainable development triggers expectations for a range of changes, specific results and outcomes, especially since education for sustainable development itself represents a complex system. Therefore, application 
of ToCh suggests that the success of interventions using education for sustainable development is based on expectations for short-, middle- and long-term changes in the existing higher education system.

For example, the Global Partnership for Sustainable Development Data (GPSDD) suggests that ToCh should integrate "actions on social, environmental and economic challenges with a focus on inclusive, participatory development that leaves no one behind" (GPSDD, 2019, p. 3). The GPSDD uses ToCh to develop its "hypotheses of change" and offers its "Theory of Change Diagram" (please see Diagram 1 in the attachment). This diagram considers working on change to be a complex endeavor and suggests that in order to successfully achieve the desired changes on the ground, there should be several levers of change.

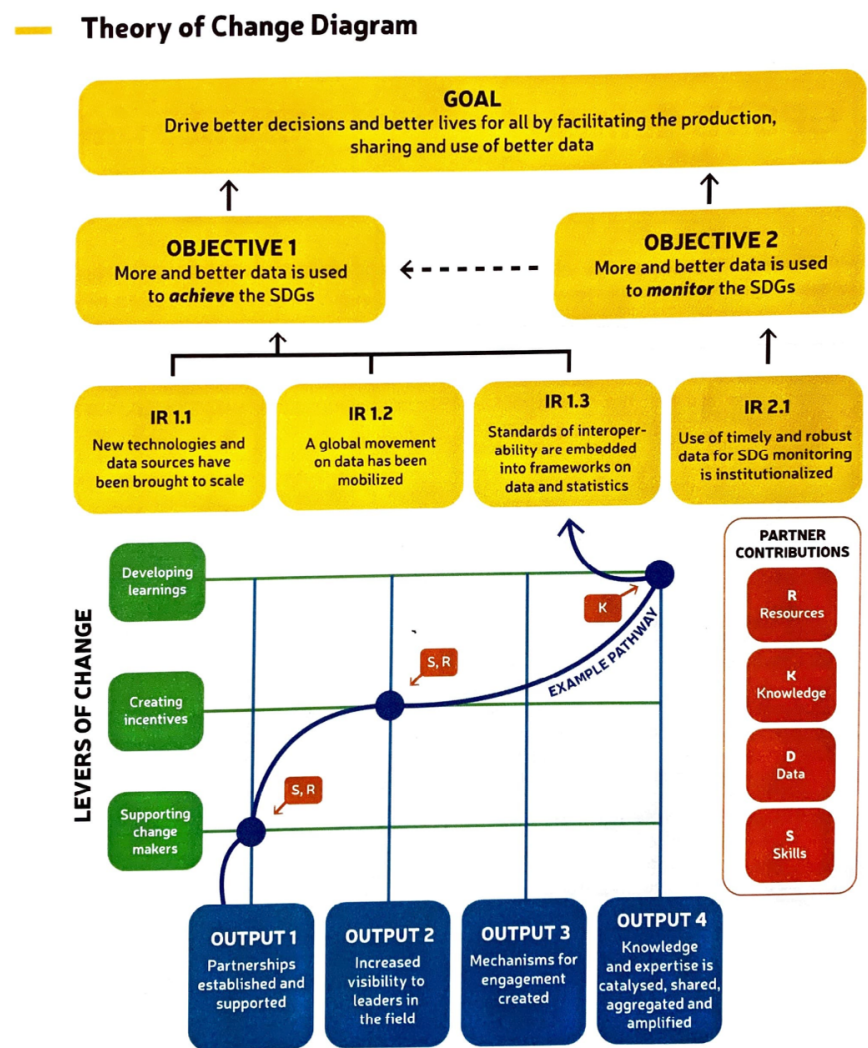

Diagram 1

Source: GPSDD (2019). Theory of Change Narrative. The Global Partnership for Sustainable Development Data. https://www. data4sdgs.org/sites/default/files/services_files/GPSDD $\% 20$ Theory\%20of\%20Change.pdf(accessed on November 20, 2020).

I would argue that in the case of the introduction of education for sustainable development, ToCh should be interpreted as a theoretical framework that offers several levers of plausible and feasible change:

Changes in the existing education system;

Changes in the regulatory policy framework in the education sector;

Changes in the education for sustainable development program itself (as it should be considered as a living mechanism adaptable to specific educational environments).
In the case of education for sustainable development, ToCh could be utilized to not only identify and explain the levers for introduction of change, but also to identify assumptions and target desirable outcomes during implementation of complex programs with clear indicators of change.

2. Education for sustainable development: background and recent development

This chapter provides a short overview of the historical background of the development of the 
conceptofeducation forsustainable development, and suggests that the method of historical reconstruction of the global intellectual discourses on the education for sustainable development and the emergence of the "cross-disciplinary approach" would help to understand better the challenges of introduction of education for sustainable development at the national level. The "cross-disciplinary approach" led to the emergence of the concept of "sustainable development practice" was implemented in the format of the MDP Program pioneered by the Earth Institute at Columbia University.

The history of the education for sustainable development could be traced to the United Nations Conference on Environment and Development (UNCED - https://www.un.org/en/conferences/ environment/rio1992) in 1992, although the discourses on sustainable development begun in the 1970s and 1980s with introduction of several important and influential studies and reports. For example, the Brundtland Commission officially released its benchmark report "Our Common Future" (also known as the "Brundtland Report") in 1987. During the UNCED, the head of 178 participating states agreed on a framework for action in Agenda 21. The chapter 36 of the Agenda 21 entitled "Promoting education, public awareness and training" "highlighted the need to increase public awareness, education and training as an important step towards achieving sustainable development in future. In addition, this document suggested "reorienting education towards sustainable development."

In fact, the UN and UN agencies have continued promoting education for sustainable development throughout the 1990s and early 2000s at major global events, including the UN Framework Convention on Climate Change (UNFCCC), the UN Convention on Biological Diversity (UNCBD) and the UN Convention to Combat Desertification (UNCCD), the UN Millennium Summit in 2000.

This attention to sustainable development and education for sustainable development allowed not only to mobilize active public support for promoting education for sustainable development, but also to conceptualize practical aspects such as developing educational programs and module, identifying specific subjects and building multi-disciplinary modules for education for sustainable development.

In the next important step, the UN General Assembly (UNGA) officially launched the Decade

\footnotetext{
https://sustainabledevelopment.un.org/content/documents/Agenda21.pdf ${ }^{2}$ Ibid, section 36
}

of Education for Sustainable Development (DESD) (2005-2014). It was envisioned that the DESD would allow the UN agencies to work on coordination of global efforts and activities of interested parties and stakeholders on improving existing educational programs and modules and assisting in integration of the education for sustainable development into national educational programs in a systematic manner. The UNGA designated UNESCO to become a lead UN agency to coordinate the work on promoting the education for sustainable development at the global and national levels.

The DESD envisioned that not only international organizations but also national governments from around the world would work in systematic ways on developing strategies and action plans to promote the education for sustainable development.

UNESCO initiated a number of activities, including organizing a series of consultations at the global, regional and national levels and preparation and publication of annual reports and research papers on the topic. One of the important aspects of the work on education for sustainable development was the development of novel and more effective educational approaches and procedures for work at several levels:

Formal education;

Non-formal education;

Informal education;

Training ${ }^{3}$

One of the important contributions to the intellectual discourses on education for sustainable development was the work of the International Commission on Education for Sustainable Development Practice (ICEDSDP). In 2007, the Earth Institute at Columbia University brought together a group of 20 prominent scholars and policy-practitioners with the support of a grant from the John D. and Catherine T. MacArthur Foundation. These scholars and practitioners represented a variety of disciplines and offered a multi-disciplinary approach to the developing and expending education for sustainable development program (Earth Institute at Columbia University (2008), p. 1-3). The Commission made an important contribution to the debates on education for sustainable development shifting emphases and focus to "practice" and identifying practical initiatives (Table 1). In fact, the Commission came up with suggestions to develop

\footnotetext{
${ }^{3}$ UNESCO, 2014. Shaping the Future We Want - UN Decade of Education for Sustainable Development (Final report). Paris: UNESCO, 2013, p. 20. https://sustainabledevelopment.un.org/content/ documents/1682Shaping $\% 20$ the $\% 20$ future $\% 20$ we $\% 20$ want.pdf
} 
education for sustainable development programs with emphases on "cross-disciplinary approach" and "sustainable development practice" (Earth Institute at Columbia University (2008), p. 5-6).

Table 1.

As the flagship of the new field, the two-year Master's in Development Practice (MDP) program would provide graduate-level students at key academic institutions around the world with the core skills and knowledge required of a generalist development practitioner.

Curriculum: MDP programs would require full-time enrollment of graduate-level students for at least two full years, and would include rigorous study of cross-disciplinary topics spanning the following core disciplines:

Health Sciences - nutrition, population sciences and reproductive health, basic epidemiology of infectious and noninfectious disease, health policy, health system design and management;

Natural Sciences and Engineering - agriculture, forestry and shery management, water management, energy, engineering, environment and climate science;

Social Sciences - anthropology, economics, education, politics and international political economies, statistics;

Management - project design and management, budget planning and financial management, commodities management, communication and negotiations, critical self-refection, geographic information systems and decision making tools, institutional resource and human resource management, information management systems and design;

Practical learning through projects, exercises and case studies: To support and enrich the core MDP curriculum, the program would integrate a variety of teaching and learning resources including practical, experiential learning through cross-disciplinary case studies and group exercises.

Source: Earth Institute at Columbia University (2008). Report from the International Commission on Education for Sustainable

Development Practice. New York: Earth Institute at Columbia University. https://www.macfound.org/media/article_pdfs/

DEVELCOMM-EXECSUMM.PDF

For practical implementation of the recommendations of the ICEDSDP, a group of universities established the MDP Global Association, which grew up from several partner MDP institutions in 2008-2009 into a truly global network of about 30 educational institutions in 2019-2020, running a regular Annual International Conference on Sustainable Development at Columbia University, New York.

Under the auspices of the UN Secretary-General was launched the UN Sustainable Development Solutions Network (SDSN) in 2012. The SDSN was established to mobilize "global scientific and technological expertise to promote practical solutions for sustainable development, including the implementation of the Sustainable Development Goals (SDGs) and the Paris Climate Agreement." According to its Chapter, the SDSN works closely with "United Nations agencies, multilateral financing institutions, the private sector, and civil society."

\section{Introduction of MDP Global Classroom program: the discussion of case study of $\mathrm{Al}$ Farabi KazNU}

The example of the work of Al Farabi KazNU on introduction of education for sustainable development at the university level and promoting it in Kazakhstan is an example of the application of the Theory of Change at the institutional level

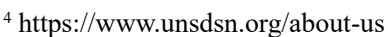

with setting dedicated short-, middle- and longterm goals and objectives. Thus, KazNU subdivided its activities on the introduction of education for sustainable development into four interconnected sets of activities.

Formulation of goals and objectives in introduction of education for sustainable development. The work on the creation of a modern program on sustainable development was actualized in the context of work and discussion with a number of international experts, including the leading European theorist of higher education - Professor Joseph Wissema. Professor Wissema presented the main ideas of his influential monograph "Towards the Third Generation University. Managing the University in Transition" during his visit to $\mathrm{Al}$ Farabi KazNU and a series of consultations with the management of the university and the major stakeholders. Professor Wissema put forward the idea that Research Universities of the 21 st century - Universities 3.0 - should integrate work in three areas: educational, research and practical (implementation of developments and theory into practice).

The opening of the MDP program on sustainable development was initiated during by the visit of the delegation of Al Farabi KazNU to Columbia University in 2011, and the signing of a cooperation agreement with the director of the Earth Institute and adviser to the UN Secretary General, Professor Jeffrey Sachs. 
During this visit to New York in 2011, the delegation of al-Farabi KazNU among others also visited the UN Headquarters and received an invitation to join than a new international initiative - UN Academic Impact Program (UNAI) (founded in 2010). ${ }^{5}$ Thus, KazNU has become a member of the UNAI and has taken leadership in promoting the education for sustainable development not only in Kazakhstan, but also in Central Asia and Afghanistan.

Advocacy work in promoting education for sustainable development. The membership in the global networks of educational institutions and close work with the UN agencies has helped Al Farabi KazNU to work on advocacy of Sustainable Development and then of Sustainable Development Goals and to participate in a series of global events presenting views and ideas of the "Global South."

For example, with the support from the UNAI Secretariat, Al-Farabi KazNU became the only university from the Commonwealth of Independent States (CIS) area that received an opportunity to hold its very own special section on education for sustainable development within the framework of the UN Global Forum on Sustainable Development RIO +20 (Rio de Janeiro, Brazil) in 2012. KazNU put forward an idea to develop the "Green Bridge through Generation" promoting education for sustainable development among youth in the "global south"

Another step was an international conference "The Changing Nature of Conflicts in the 21st Century" on October 17-18, 2012, dedicated to the 20th anniversary of Kazakhstan's accession to the UN. It was conducted with the assistance of the UN Department of Public Information in Kazakhstan. Among the participants were the Head of the UN Academic Impact Program Mr. Ramu Damodaran, Director of the Outreach Division of the UN Department of Public Information Mr. Maher Nasser, Representative of the UN Department of Public Information in the Republic of Kazakhstan Mr. Vlastimil Samek and some others.

Gradually, KazNU became a focal point in Kazakhstan for organizing global, regional and national events on education for sustainable development. For example, in 2014, KazNU hosted an international conference "New paradigm of sustainable human development" dedicated to the global problems of humanity and sustainable social and economic development in the region. More than four hundred scientists, educators and international

\footnotetext{
${ }^{5}$ For additional information about the UNAI, please follow the link: https://academicimpact.un.org/content/about-unai
}

experts from 22 countries of the world took part in the conference developing a series of recommendations on promoting sustainable development.

The next important benchmark was achieved in 2014, as KazNU received an important proposal to lead the Global Hub of United Nation Academic Impact (UNAI) on Sustainability working on the implementation of international initiatives of the United Nations, UNDP, UNICEF, and UNESCO. The Global Hub of UNAI status was actively renewed three times.

In 2015, the UNGA adapted the 17 interlinked Sustainable Development Goals (SDGs) to be achieved by the year 2030 and included into the UN Resolution called the UN Agenda 2030. ${ }^{6}$ KazNU contributed to global discourse on the SDGs supporting an important initiative - global consultations "The Future We Want".

In 2016-2018, the Global Hub of UNAI on Sustainability at KazNU worked closely and coordinated the activities of the UNESCO Chair in Journalism and the UNESCO Chair in Sustainable Development on integrated scientific and applied research in the field of sustainable development. In 2018, the Global Hub of UNAI jointly developed an online course on Global Citizens Education (GCE) jointly with the UNESCO Chairs of KazNU and, for the first time in Kazakhstan, implemented it on the MOOC online platform for teaching KazNU and Central Asian students to address the global problems of humankind.

Introduction of education for sustainable development into formal curricular at the university level. A good example of the implementation of the educational component has been the MDP/GLOBAL CLASSROOM PROGRAM on Sustainable Development. In general, our program is characterized by the statement of Steve Jobs, who said that innovative education makes a person a leader! That is why MDP-Global Classroom at KazNU payed a great deal of attention to innovative and interactive forms of education in the program of studying the entire set of subjects on the Sustainable Development Goals (SDGs). Firstly, training in the Foundation of Sustainable Development Program has been conducted in a case-study based format (approximately 6-10 real projects-case studies per year), taking into account an interdisciplinary approach (KazNU became the first university in Kazakhstan to introduce a course on sustainable development into the curriculum).

\footnotetext{
${ }^{6} \mathrm{https}: / /$ sustainabledevelopment.un.org/content/documents/21252030\%20 Agenda $\% 20$ for $\% 20$ Sustainable $\% 20$ Development $\% 20$ web.pdf
} 
Secondly, KazNU introduced teaching project management in an international format, that is, trying to transfer effective foreign management know-how utilizing best practices from the USA, South Korea, etc. Thirdly, MDP students spent designated time working on specific and important projects - these can be ideas for startups, projects for sustainable development in Kazakhstan and many others. The main goal for students has been to master the skills for the real international work on real international projects, on real startups and real research projects. These students devote most of their time to international project, sometimes even traveling foreign countries including USA, France and Italy for internships, but still staying and studying at KazNU. Why do we pay special attention to sustainable development projects?

The MDP Program on sustainability - on which the world is going to spend more than a trillion dollars by 2030 - evolved around the three whales that hold our planet. One whale is an economic whale, that is, an economy that finances and helps to develop our lives, offering us various opportunities for development. The second whale is social (society), that is, people who have their connections, their relationships, their own difficulties and problems, over which they must work together at all levels from local to national and global. And the third whale is the environment and ecology. Unfortunately, over the past decades, the environment in many countries and around the world has deteriorated sharply (including deforestation and desertification). Therefore, it is necessary to take appropriate measures, and this requires financial resources (economic aspect), the will of the population and all citizens (social aspect) to solve challenges of climate change and environmental degradation (environmental problems).

An example of the implementation of the research component is the research work of undergraduates and doctoral students. We use the slogan of Bill Gates (founder of Microsoft) - "If something doesn't suit you at work, start your own business. I started a business in a garage! " I think the most successful projects implemented by the students have been life-based projects that can help students start their own business.

Introduction of sustainable development practice into formal curricular through capstone projects. In an important step, the MDP/GLOBAL CLASSROOM PROGRAM steering committee recommended to encourage students to work on several capstone projects (6 to 8 projects per year). Every year the management of MDP in consultations with the MDP Steering Committee selected 6-8 capstone projects through brainstorming using ICT, discussions with faculty, as well as through consultations with UN agencies in Kazakhstan. The MDP management has coordinated both the desk-research on and the implementation of these projects with the local stakeholders. The students scrupulously studied the international experience (UNECE, 2019) in order to "transfer" best practice to Kazakhstan (OECD, 2018). For example, the Biking-Habitat ("world of the bicycle") was one of such successful projects. In cooperation with the UNDP in 2012-2015, MDP students conducted a series of questionnaire-based studies among young people to find out if they really want to use bicycles in everyday life, and if so, on what conditions. The key question was as follows: "what should be done in terms of changing infrastructure in the city to promote bicycling among the youth?" Another very successful project MDP had in 2016-2017 was the study of social entrepreneurship among women, as the students were able to meet women social entrepreneurs in Almaty and the Almaty region and learned what projects they were working on and what business they were developing. The most interesting project that we are developing in 20182019 was associated with the large capstone project and research program, called "Smart-city, Smart campus". Within its framework, students worked on ten topics, and explored the problem of "smart city" from different angles. The most interesting conclusion was that Almaty can not only learn from foreign countries about new technologies and best practices, but Almaty can also share its experience with other cities of the world. For example, MDP students from Afghanistan worked on the "Kabul - Smart City" project, believing that Almaty has experience that can be transferred to the capital of Afghanistan - the city of Kabul. A successful project was also on T-shirts for children, which were covered with a special luminescent coating that glowed in the dark, so children - if they went out on the road in the evening, wearing such a T-shirt - were visible from a distance to the drivers (and these students later set up their own startup producing T-shirts). The students from the faculty of journalism developed a very interesting project related to the development of applications for phones and other gadgets - a kind of children's game for sustainable development, i.e. the application teaches children to save water, save electricity and other resources, and contribute to the greening of the city, planting flowers and trees. Moreover, the students envisioned the App in three languages - Kazakh, Russian and English. 


\section{Conclusion}

The conclusion summarizes the findings of the article focusing on the ways in which ToCh can explain the introduction of education for sustainable development and the achievements of the MDP Program at KazNU. The overview of the implementation of the MDP Program (See chapter 3) suggests that the main part of the success was an ability to subdivide major goals and objectives into concrete steps and short-, middle-, and long-term objectives.

As per the discussion in Chapter 3, ToCh provided an important theoretical framework for the introduction of education for sustainable development, that offered several levers of plausible and feasible changes and helped to structure the effective work on the implementation of the MDP Program at KazNU in collaboration with the MDP Global network and the UN SDSN. One of the most important results of a decade of work of MDP Program at KazNU (2011-2020) on educational, research and practical work in the field of sustainable development and flagship MDP Program has been the fact that the university has not only become a leading institution in the field of education and research on sustainable development in Kazakhstan, but throughout Central Asia. During this period, the MDP students completed about 50 case studies on sustainable development issues, won about a dozen of national and international awards and competitions and volunteered at several national events (Abazov, R., (Interview) (2019). In addition, the faculty members of KazNU provided an important intellectual and practical support and numerous consultations on the implementation of state programs - "Kazakhstan-2050," "Digital Kazakhstan," "Almaty Sustainable City," "Smart Campus" program and many others (Strategy 2050, 2020).

The successful introduction of education for sustainable development into formal curricular at the university level through the introduction of MDP/GLOBAL CLASSROOM PROGRAM on Sustainability and a decade of active advocacy work in promoting education for sustainable development and the SDGs among universities in great Central Asian region received recognition at the regional and international levels. In May 2018 the decision was made to open the Ban Ki-moon Institute for Sustainable Development. Mr. Ban Ki- moon, the 8th Secretary General, personally visited Kazakhstan to participate in the Astana Economic Forum (AEF-2018) and signed a Memorandum of Understanding on the opening of the Institute and giving his personal consent to give his name to the name of this Institute Ban Ki-Moon Institute for Sustainable Development(BKMISD). The BKMISD brought together wealth of experience of KazNU's work on promoting education for sustainable development in Kazakhstan and in the region and it became a magnet mobilizing university staff to contribute to increasing contribution of Kazakhstan to implementation of the SDGs (UNESCAP, 2020).

In 2018-2019, the BKMISD coordinated a large interdisciplinary research project, together with ERASMUS Smart City, MDP/Global Classroom, UNESCO Chair in Journalism and UNESCO Chair for Sustainable Development, conducted a large-scale study and published a monograph «Smart Cities on the Silk Road» (Mutanov G., 2019), which analyzed major regional and global urbanization trends. This included such topics as how market-oriented economic development and SDGs would integrate into the concept of sustainable development in the formation of a sustainable economy in general and sustainable smart cities in particular, the creation of «green» jobs and the development of a «green» economy and "green" cities, both in Kazakhstan and in the Silk Road region (Mutanov G., 2019). The results of the study and the practical recommendations of the monograph "Smart Cities on the Silk Road" (2018-2019) were presented to national and international policymakers at several seminars and workshops. The policymakers in Kazakhstan have indicated their interest in supporting education for sustainable development (educational, research and practical work on sustainable development issues) at several official documents (see: EGOV. KZ, 2020).

Within this framework of collaboration with various stakeholders, KazNU plans continuing to develop its portfolio in publishing, and actively working on SDG-related topics. This included further in-depth studies of the development of "smart sustainable cities" and smart and green campuses using ICT tools, digitalization, gamification, innovative approaches to supporting and promoting green startups and technoparks through the training of highly qualified personnel for high-tech industries. 


\section{References}

Abazov Rafis (Interview) (2019), Na kogo uchitsia v tsifrovom stoletii [“Who to study in the digital century?"]. Arguments i Facty (Kazakhstan), January 30, 2019, (journalist - Yulia Katsman). In Russian. https://aif-kaz.kz/node/3207?fbclid=IwAR0KLef9 42WIaezBVvXXfuuzEUINILpYwb_fkjXPU3X1NEFy4b3VjZlQk-0 (accessed on April 20, 2019)

Abazov, Rafis, and Elmira Alim. (2012). Observing the Global Financial Crisis from the Developing World: The Case of Kazakhstan. Asian Politics and Policy, 4. 276-278.

Abazov Rafis (Interview) (2016), Opyt Kazakhstana unikalen dlia vsei evrazii [the experience of Kazakhstan is unique for entire Eurasia]. Dialogue (Kazakhstan) November 24, 2016. In Russian. http://www.dialog.kz/articles/obshchestvo/2016-11-24/rafisabazov-opyt-kazahstana-unikalen-dlya-vsey-evrazii (accessed on April 20, 2020).

Abazov, Rafis (Interview) (2019), "Lifelong learning." LITER, March 02, 2019.(In Russian). https://old.liter.kz/ru/articles/ show/56649-lifelong learning(accessed on November 20, 2020).

GPSDD (2019). Theory of Change Narrative. The Global Partnership for Sustainable Development Data. https://www.data4sdgs.org/sites/default/files/services_files/GPSDD\%20Theory\%20of\%20Change.pdf(accessed on November 20, 2020).

Global Association MDP. Online resources and webspage. http://mdpglobal.org/

Janos, Andrew C. (1986). Politics and Paradigms: Changing Theories of Change in Social Science.Stanford: Stanford University Press.

Jahdhami, Adnan Al (2019). Theory of Change: Between Leadership and Modern Education. Singapore: Partridge Publishing Singapore.

Kubisch, A. (1997). Voices from the field: Learning from the early work of comprehensive community initiatives. Washington, DC: Aspen Institute.

Earth Institute at Columbia University (2008). Report from the International Commission on Education for Sustainable Development Practice. (The International Commission on Education for Sustainable Development Practice was commissioned by the Earth Institute at Columbia University and sponsored by the John D. and Catherine T. MacArthur Foundation). New York: Earth Institute at Columbia University. Accessible: https://www.macfound.org/media/article_pdfs/DEVELCOMM-EXECSUMM.PDF (accessed on November 20, 2020).

Mutanov G. (ed.) (2019) Smart Cities on the Silk Road: International Experience of Sustainable Development of Cities. Almaty: Kazak Universiteti.

EGOV.KZ (2020). ЦелиустойчивогоразвитиявРеспубликеКазахстан[Sustainable Development Goals in the Republic of Kazakhstan]. Online database in Russian. https://egov.kz/cms/ru/zur(accessed on November 20, 2020).

OECD (2018). Fostering Students' Creativity and Critical Thinking - What it Means in School. Educational Research and Innovations. Paris: OECD, 2019. https://en.dl-servi.com/product/fostering-students-creativity-and-critical-thinking-what-it-means-inschool(accessed on November 20, 2020).

OECD (2018). Higher Education in Kazakhstan 2017. Paris: OECD, 2017.

Strategy 2050 (2020). ПоКакимПоказателямЦУРКазахстаномДостигнутыРезультаты [On Which SDG Indicators Kazakhstan Achieved Results]. Online database in Russian. https://strategy2050.kz/ru/news/po-kakim-pokazatelyam-tsur-kazakhstanomdostignuty-rezultaty-/(accessed on November 20, 2020).

UNECE (2019). Environmental performance reviews. Kazakhstan: third review. United Nations Economic Commission for Europe. Geneva: United Nations. http://www.unece.org/fileadmin/DAM/env/epr/epr_studies/kazakhstan.pdf(accessed on November 20, 2020).

UNESCAP (2020). МониторингпоказателейЦУРвРеспубликеКазахстан [Monitoring of the SDG indicators in Kazakhstan]. Almaty: UNESCAP, 2020. (In Russian). https://www.unescap.org/sites/default/files/Session4_Kazakhstan_SDG_indicators_Russian.pdf (accessed on November 20, 2020).

UNESCO (2014), Shaping the Future We Want: UN Decade of Education for Sustainable Development (2005-2014). Final Report. Paris: UNESCO. https://sustainabledevelopment.un.org/content/documents/1682Shaping\%20the $\% 20$ future $\% 20$ we $\% 20 \mathrm{want}$. pdf(accessed on November 20, 2020).

UNESCO (2020), Global Education Monitoring Report 2020 Inclusion and education: All means all. Paris: UNESCO. https:// en.dl-servi.com/product/global-education-monitoring-report-2020-inclusion-and-education:-all-means-all(accessed on November 20, 2020).

UNESCO (2020), Issues and trends in education for sustainable development. Paris: UNESCO: 2020. https://en.dl-servi.com/ product/issues-and-trends-in-education-for-sustainable-development(accessed on November 20, 2020).

Wissema, J.G. (2009). Towards the Third Generation University. Managing the University in Transition. New York: Edward Elgar. 